\title{
Marlene's house
}

\author{
Keywords \\ Poetics, Creative process, Photography, Installation, Performance.
}

As an artist-researcher, I have been developing the research "Marlene's house" in the Doctorate in Arts, Graduate Program in Arts, Institute of Art Sciences, Federal University of Pará, since 2018. An extension of the research I produced in the Master's Degree in Arts, at the same institution of higher education, from 2016 to 2018. It is a poetics built from family and affective memory, in which photography, video, sound, writing, smell, taste, touch and feeling merge. And it is part of research line 1, on poetics and acting processes, dedicated to research in the arts, with a focus on poetics, on modes of acting, on the construction and presentation of an artistic work, accompanied by a reflective text. Thus, the research is being built with a memorial that houses the reflective text and a work, consisting of an installation with photography-video-sound-writing, records of my mother's house. Along the way, I talk to researcher Priscila Arantes, from São Paulo, who writes: "expanded field photography incorporates [...] the idea of dialogue, contamination and intersections of the field of photography with other fields of language and know." I also talk to the American Rosalind Krauss, who studies three-dimensional work and its expanded field. As a personal methodology, I mentally create a garden mixed with my memories of the garden of the house where I lived, where I develop the installation and the memorial. A meditation in which there is the action of artistic making. And it is in this garden that I experiment, read, research, edit photography-video-sound-written, reflect on my life path and what touches me throughout it, and write the research texts. During classes, in practical-reflective studies, I have been building my poetics, experimenting with installations in the classroom. One of them related to the kitchen of the house where I lived. I tried, in two subjects, the coffee experience with classmates. A performance I talk to Renato Cohen about, when he says that this creative act touches the tenuous boundaries that separate life and art. Each layer of the installation is perceived in the creative process of the artwork. And, based on what I perceive in my poetics, I develop conversations with the history of art, and I have conceived texts, which I named the artist's writings. With the letters, words, sentences and reflections, I write down what I thought/think about geometry, dimensions, space, the room in the house and sharing around a dining table. The poetic layers built in the creative path are countless and, in the installation, I present traces that are in me, in the garden, in the bedroom, in the kitchen and in the backyard where I lived a life in my mother's house. 